\title{
Biomineralization in plants as a long-term carbon sink
}

\begin{abstract}
Carbon sequestration in the global carbon cycle is almost always attributed to organic carbon storage alone, while soil mineral carbon is generally neglected. However, due to the longer residence time of mineral carbon in soils $\left(10^{2}-10^{6}\right.$ years), if stored in large quantities it represents a potentially more efficient sink. The aim of this study is to estimate the mineral carbon accumulation due to the tropical iroko tree (Milicia excelsa) in Ivory Coast. The iroko tree has the ability to accumulate mineral carbon as calcium carbonate $\left(\mathrm{CaCO}_{3}\right)$ in ferralitic soils, where $\mathrm{CaCO}_{3}$ is not expected to precipitate. An estimate of this accumulation was made by titrating carbonate from two characteristic soil profiles in the iroko environment and by identifying calcium (Ca) sources. The system is considered as a net carbon sink because carbonate accumulation involves only atmospheric $\mathrm{CO}_{2}$ and $\mathrm{Ca}$ from Ca-carbonate-free sources. Around one ton of mineral carbon was found in and around an 80-year-old iroko stump, proving the existence of a mineral carbon sink related to the iroko ecosystem. Conservation of iroko trees and the many other biomineralizing plant species is crucial to the maintenance of this mineral carbon sink.
\end{abstract}

\section{Introduction}

During the last decade, the carbon cycle has been extensively studied in connection with research on climate change. Although land carbon sequestration in the global carbon cycle is always taken into account (as soil organic matter; Prentice et al. 2001), soil mineral carbon trapping is generally neglected. Yet a soil mineral carbon sink is potentially of great interest for two reasons: (1) the residence times for mineral carbon $\left(10^{2}-10^{6}\right.$ years; Retallack 1990) is up to 100,000 times longer than for soil

G. Cailleau · O. Braissant · E. P. Verrecchia (

Institut de Géologie, Université de Neuchâtel,

Rue Emile Argand 11, 2007 Neuchâtel, Switzerland

e-mail: eric.verrecchia@unine.ch

Fax: +41-32-7182601 organic matter carbon $\left(10^{1}-10^{3}\right.$ years; Prentice et al. 2001) and (2) hundreds of plant species are known to mineralize (Simkiss and Wilbur 1989). The tropical iroko tree Milicia excelsa from Ivory Coast is probably one of the most impressive examples of these mineralizing plants (Braissant et al. 2003). Not only does it have the capacity to mineralize a high percentage of its tissues (from trunk to roots; Campbell and Fisher 1932), but this process directly contributes to accumulations of $\mathrm{CaCO}_{3}$ in the tree's surrounding ferralitic soil (Carozzi 1967), in which (theoretically) carbonate should not be able to precipitate because of the acidic conditions. Thus, the iroko tree is an ideal example to use for studying a mineralizing plant's capacity to accumulate mineral carbon.

The second aim of this study is to evaluate the potential importance of irokos and similar mineralizing plants as a carbon sink. There are many definitions of the term "carbon sink". Elbersen et al. (1999) consider that there are two possible origins for the $\mathrm{Ca}$ in pedogenic $\mathrm{CaCO}_{3}$. Ca can be inherited from weathering of preexisting $\mathrm{CaCO}_{3}$ (e.g. dust or parent rock). Recrystallization of $\mathrm{CaCO}_{3}$ allows atmospheric $\mathrm{CO}_{2}$ catchment but, in contrast, fossil $\mathrm{CO}_{2}$ has been released during weathering, leading to a zero net balance for the carbon cycle. Thus, this is only a molecular $\mathrm{CO}_{2}$ substitution. A second possible origin of $\mathrm{Ca}$ is when it has been released from the weathering of non-carbonate minerals and precipitates as $\mathrm{CaCO}_{3}$. In this case, the catchment of atmospheric $\mathrm{CO}_{2}$ by the released $\mathrm{Ca}$ into "authigenic $\mathrm{CaCO}_{3}$ acts as a carbon sink" (Elbersen et al. 1999). The latter definition is the most appropriate for this study.

\section{Materials and methods}

During the last 50 years, deforestation in Ivory Coast has led to the disappearance of approximately three-quarters of the original rainforest. The iroko tree grows in the rainforest (southern part), as well as in the savanna (northern part) of Ivory Coast (Ministère du Plan de Côte d'Ivoire 1979). This valuable species has been extensively logged and is now almost entirely restricted to national parks and reserves. In Biga (Daloa County, Ivory Coast, $7^{\circ} 32^{\prime} \mathrm{E}$, $\left.6^{\circ} 36^{\prime} \mathrm{N}\right)$, two profiles have been studied, one at a distance of $0.50 \mathrm{~m}$ 
from the remaining iroko trunk (Profile A) and the second in the hollow trunk and directly underneath (Profile B). In theory, ferralitic soils are acidic, the $\mathrm{pH}$ ranging from 4.3 to 6 . Nevertheless, at the Biga site, the $\mathrm{pH}$ is between 7.9 and 9.0 (with an average of 8.5) around the tree.

Because of the totally different amounts of $\mathrm{CaCO}_{3}$ in the two profiles, two methods have been used to determine the $\mathrm{CaCO}_{3}$ content. In Profile A, in which carbonate content is $<20 \%$ by weight, a titration using sulphuric acid $(0.5 \mathrm{~N})$ and sodium hydroxide $(0.5 \mathrm{~N})$ was performed on $1 \mathrm{~g}$ of crushed bulk sample. In Profile B, some samples contain $>30 \%$ by weight of carbonate. Concentrations were determined by mass difference between $1 \mathrm{~g}$ of original crushed bulk sample before and after carbonate dissolution in $10 \%$ hot hydrochloric acid. The percentage by weight is determined by titration and a mean value is calculated for each $20-\mathrm{cm}$ layer for both volumes (torus and cylinder). By knowing the soil density for both volumes, the total $\mathrm{CaCO}_{3}$ content is then calculated with an underestimation to give an approximate magnitude of the mineral carbon pool.

\section{Results}

In iroko trees, large accumulations of $\mathrm{CaCO}_{3}$ are present, from blocks of $1.5 \mathrm{~m}$ wide to micro- and nano-scale forms, because of a peculiar oxalate-carbonate biogeochemical cycle (Fig. 1). This cycle demonstrates that calcium oxalate produced by both plants (Horner and Wagner 1995) and fungi (Cromack et al. 1977; Gadd 1999) can be transformed into $\mathrm{CaCO}_{3}$ by bacteria
(Braissant et al. 2002). The $\mathrm{pH}$ increase induced by this cycle is favourable to $\mathrm{CaCO}_{3}$ precipitation and accumulation, as carbonic acid is weaker $\left(\mathrm{pK}_{1}=6.35 ; \mathrm{pK}_{2}=10.33\right)$ than oxalic acid $\left(\mathrm{pK}_{1}=1.25 ; \mathrm{pK}_{2}=4.27\right)$. Moreover, as oxalate is a poor substrate for bacterial growth, only $5 \%$ of this carbon source is transformed into biomass, whereas $95 \%$ leads to carbonate ion formation, enhancing accumulation (Harder et al. 1974).

Three sources of $\mathrm{Ca}$ have been identified in the iroko ecosystem (see Fig. 1): (1) the granite parent rock, (2) dust, and (3) rain. The study of thin sections of the calcoalkaline granite parent rock shows that carbonate minerals are absent. $\mathrm{Ca}$ is mainly provided by the plagioclases, and to a lesser extent by amphiboles and pyroxenes. Ca present in the rain (rainfall of 2,500 $\mathrm{mm}$ per year) is in the ionic state (i.e. dissolved). Dust is provided to the system during the dry season (from December to January). The southwesterly wind responsible for this mass transport is the Harmattan. X-ray diffraction analyses have only revealed the presence of quartz and kaolinite (Stoorvogel et al. 1997). These minerals cannot explain the presence of calcium (kaolinite is not able to adsorb $\mathrm{Ca}^{2+}$ ). It is likely that $\mathrm{Ca}$ is trapped in eolian organic matter. In the absence of $\mathrm{Ca}$ input from carbonate rocks, it is obvious that accumulations of secondary carbonate associated with iroko trees constitute a carbon sink. In summary, the iroko
Fig. 1 Carbon cycle associated with the iroko tree ecosystem, Ivory Coast. Atmospheric $\mathrm{CO}_{2}$ is fixed by the tree, which produces biomass and oxalate. Another pool of oxalate is produced by fungi, which feed on the tree. This oxalate is used by fungi to decay plant tissues (mainly cellulose and lignin). Finally, all the oxalate can be used by bacteria as a carbon source, resulting in carbonate ion production, and $\mathrm{CaCO}_{3}$ precipitation

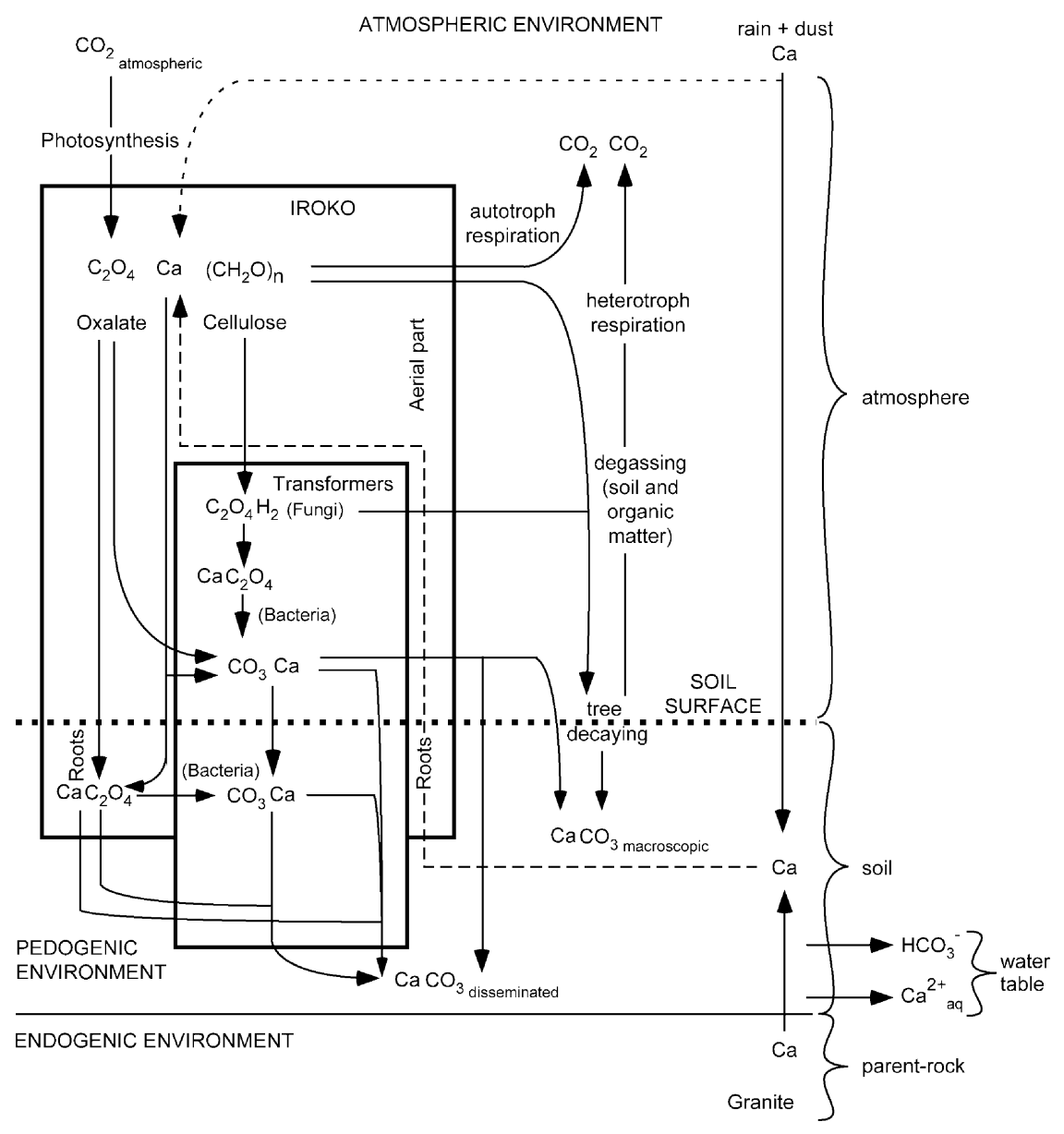




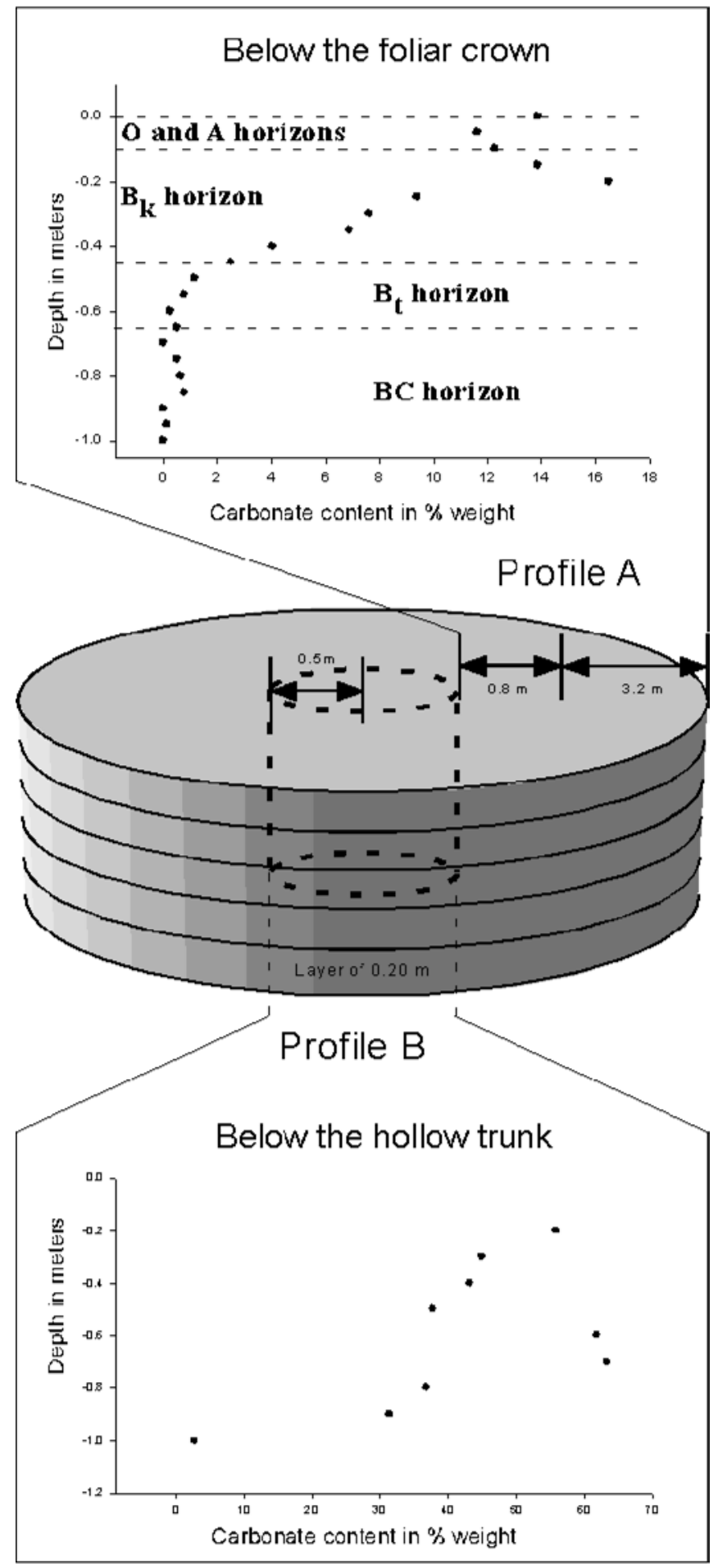

Fig. 2 Description of the method used to quantify $\mathrm{CaCO}_{3}$ accumulation around an iroko tree. Overestimation for this quantification is excluded because the highly calcified stump, as well as the largest blocks of carbonate inside the torus, are not taken into account in the calculations. $\mathrm{CaCO}_{3}$ content is determined for each 20 -cm-thick layer. The carbonate content is assumed to be constant in each layer of the two soil volumes. For the torus, a decrease in carbonate content is obvious when moving away from the tree (compared with the high carbonate content below the trunk). $\mathrm{CaCO}_{3}$ is considered to be absent out of the whole volume considered in the calculations. Nevertheless, this approximation remains the best average in the absence of more data ecosystem represents a potential net positive balance for carbon sequestration.

Quantification of the potential mineral carbon sink given in this study is an underestimation of the mineral carbon content because the mineralized tissues of the tree itself are not taken into account (i.e. the tree above the ground level as well as living but partly mineralized tissues such as roots). The system is considered as a cylinder of $9 \mathrm{~m}$ in diameter, outside of which the carbonate content is considered as nil because the soil does not react with $\mathrm{HCl}$ beyond $4.5 \mathrm{~m}$ from the centre of the trunk. This cylinder is composed of two parts (Fig. 2), (1) a cylinder of $1 \mathrm{~m}$ in diameter corresponding to the projection of the hollow trunk, in which the $\mathrm{CaCO}_{3}$ content is given by Profile B and (2) a torus, in which the amount of $\mathrm{CaCO}_{3}$ is given by Profile $\mathrm{A}$. The $\mathrm{CaCO}_{3}$ content is first calculated using 0.20 -m-thick layers, in which the concentration of $\mathrm{CaCO}_{3}$ is considered to be approximately constant. The $\mathrm{CaCO}_{3}$ content inside each individual layer is then totalled to give the amount of $\mathrm{CaCO}_{3}$ around the tree. The total amount of mineral carbon trapped during the life of the 80-year-old tree is estimated at $979 \mathrm{~kg}$, which is equivalent to $12.25 \mathrm{~kg}$ of C/ year inside the soil. By comparing the extent of Ivory Coast's primary rainforest (16 million ha; EFI 2003) to the twentieth-century forest (3.5 million ha; Brou 1999, cited in EFI 2003), the mineral carbon sink deficit during 1 year can be calculated. Although, the density of irokos has been estimated as 1-3 specimens per hectare (FAO 2003), only 1 tree/ha is taken into account in this study in order to minimize the risk of overestimation. Moreover, this calculation was only made for the rainforest because of the lack of data for tree density in savannas. Therefore, the annual mineral carbon sink deficit due to the iroko system can be estimated as a minimum of $1.53 \times 10^{-4} \mathrm{PgC}$ for Ivory Coast. Associated organic carbon, i.e. the tree and the soil organic matter, is not taken into account in these calculations.

\section{Discussion and conclusion}

Secondary soil carbonate pools are well known (e.g. calcrete, caliche) but they are almost never considered in the global carbon balance, undoubtedly because: (1) processes involved in their formation are poorly understood and (2) they are mainly considered as $\mathrm{CaCO}_{3}$ redistributions with a zero net balance for the terrestrial carbon cycle. Nevertheless, the existence of a mineral carbon sink (in the form of $\mathrm{CaCO}_{3}$ ) due to the iroko tree ecosystem (via the oxalate-carbonate cycle; see Fig. 1) has demonstrated that carbon organic matter is not the only carbon trap that must be considered in the terrestrial carbon cycle. This mineral carbon sink can be compared to the global $\mathrm{CO}_{2}$ emissions of volcanoes.

Global $\mathrm{CO}_{2}$ emissions to the atmosphere by volcanoes (Williams et al. 1992) are a source of $2.94 \times 10^{-2}$ to $5.18 \times 10^{-3} \mathrm{PgC}$. The annual mineral carbon sink deficit due to deforestation in Ivory Coast is $1.53 \times 10^{-4} \mathrm{PgC}$. This 
result takes into account only one species (irokos) and only its distribution in the rainforest (savannas have been ignored). By comparing these figures, soil mineral carbon sequestration for one country and one tree species is only one to two orders of magnitude lower than global volcano $\mathrm{CO}_{2}$ emissions. Therefore, particular attention should be paid to deforestation, and not only for reasons of biodiversity preservation. In addition, the difference in sustainability of soil organic matter versus mineral carbon (as carbonate) pools demonstrates that biomineralization, i.e. the transformation of atmospheric $\mathrm{CO}_{2}$ into "geological" carbonate, must have had a considerable and longer impact on $\mathrm{CO}_{2}$ concentration, in the present and past atmospheres. In conclusion, biologically-induced mineralization in the Plant Kingdom undoubtedly constitutes a more efficient and longer term carbon sink than carbon sequestration by soil organic matter.

Acknowledgements The authors thank the CSRS (Swiss Science Research Centre, Abidjan, Ivory Coast) and Mr. E. Bomisso, Université de Cocody, Abidjan, Ivory Coast. Two anonymous reviewers helped to improve the manuscript. This work is supported by the Swiss National Science Foundation, grant no 2153065174.01 .

\section{References}

Braissant O, Verrecchia EP, Aragno M (2002) Is the contribution of bacteria to terrestrial carbon budget greatly underestimated? Naturwissenschaften 89:366-370

Braissant O, Cailleau G, Dupraz C, Aragno M, Verrecchia EP (2003) Biomediated carbonate storage: a longer term carbon sink than organic matter. In: 4th Swiss Global Change Day, April 4, 2003, Bern, Switzerland

Campbell WG, Fisher RC (1932) The composition and origin of "stone" in Iroko wood (Chlorophora excelsa, Benth. and Hook. f.). Emp For J 11:244-245

Carozzi AV (1967) Recent calcite-cemented sandstone generated by the equatorial tree iroko (Chlorophora excelsa), Daloa, Ivory Coast. J Sediment Petrol 37:597-600
Cromack K, Sollins P, Todd RL, Fogel R, Todd AW, Fender WM, Crosley ME, Crosley DA (1977) The role of oxalic acid and bicarbonate in calcium cycling by fungi and bacteria: some possible implications for soil animals. Ecol Bull Stockholm 25:246-252

EFI (2003) European Forest Institute: http://www.efi.fi/cis/english/ creports/ivory_coast.php

Elbersen GWW, Davie G, Van Reeuwijk LP, Janssen RPT (1999) The carbon sink function of calcic horizons quantified by means of stable isotopes of strontium. In: 6th International Meeting on Soils with Mediterranean Type of Climate. Section II, Soil Chemistry, pp 105-107

FAO (2003) Food and Agriculture Organisation http://www.fao. org/docrep/n6845f/n6845f03.htm

Gadd GM (1999) Fungal production of citric and oxalic acid: importance in metal physiology and biochemical processes. Adv Microb Physiol 41:47-92

Harder W, Wiersma M, Groen L (1974) Transport of substrates and energetics of growth of Pseudomonas oxalaticus during growth on formate or oxalate in continuous culture. J Gen Microbiol 81:ii-iii

Horner HT, Wagner BL (1995) Calcium oxalate formation in higher plants. In: Khan SR (ed) Calcium oxalate in biological systems. CRC, Boca Raton, pp 53-72

Ministère du Plan de Côte d'Ivoire (1979) Atlas de Côte d'Ivoire. Association de l'Atlas de Côte d'Ivoire, Abidjan, Côte d'Ivoire

Prentice IC, Farquhar GD, Fasham MJR, Goulden ML, Heimann M, Jaramillo VJ, Kheshgi HS, Le Quéré C, Scholes RJ, Wallace DWR (2001) The carbon cycle and atmospheric carbon dioxide. In: Houghton JT, Ding Y, Griggs DJ, Noguer M, Linden PJ van der, Dai X, Maskell K, Johnson CA (eds) Climate change 2001: the scientific basis. Contribution of Working Group I to the Third Assessment Report of the Intergovernmental Panel on Climate Change. Cambridge University Press, Cambridge, pp 183-237

Retallack GJ (1990) Soils of the past: an introduction to paleopedology. Unwin-Hyman, London

Simkiss K, Wilbur KM (1989) Biomineralization, cell biology and mineral deposition. Academic Press, San Diego

Stoorvogel JJ, Van Breemen N, Janssen BH (1997) The nutrient input by Harmattan dust to a forest ecosystem in Côte d'Ivoire, Africa. Biogeochemistry 37:145-157

Williams SN, Schaefer SJ, Calvache ML, Lopez D (1992) Global carbon dioxide emission to the atmosphere by volcanoes. Geochim Cosmochim Acta 56:1765-1770 